\title{
A Divided Supreme Court Adopts Discovery Amendments to the Federal Rules of Civil Procedure
}

\author{
Jack H. Friedenthal $\dagger$
}

In April 1980 the United States Supreme Court promulgated ${ }^{1}$ a set of amendments ${ }^{2}$ to the Federal Rules of Civil Procedure, to take effect August 1, 1980. Justice Powell, jomed by Justices Rehnquist and Stewart, wrote an opinion dissenting fron the adoption of certain of the amendments-those to Rules $26,33,34$, and 37, "the cluster of Rules authorizing and regulatimg discovery generally, interrogatories, production of documents, and sanctions for failure to make discovery."3 Although disagreement among niembers of the Court as to new rules is not unprecedented, ${ }^{4} \mathrm{~m}$ the past dissents have been based on disagreement with the substance of the proposed changes. ${ }^{5}$ In the present case, the dissenting Justices approved of the effort to reform discovery practice, but insisted that additional changes to the discovery rules are necessary. As Justice Powell stated:

I do not dissent because the modest aniendments recommended by the Judicial Conference are undesirable. I simply beheve that Congress' acceptance of these tinkering changes will delay for years the adoption of genuinely effective reforms. The process of change, as experience teaches, is tortuous and contentious. Favorable Congressional action on these ainendments will create complacency and encourage inertia. Meanwhile, the discovery rules will continue to deny justice to those

$\dagger$ George E. Osborne Professor of Law, Stanford University Law School. A.B. 1953, Stanford University; J.D. 1958, Harvard University.

1. Amendments to the Federal Rules of Civil Procedure, 85 F.R.D. 521 (1980). The Supreme Court Order amending the federal rules will ultimately appear in the United States Reports; it may be found currently at 48 U.S.L.W. 4497-4500 (May 6, 1980).

2. The amendments modified Rules 4(a), (c); 5(d); 26(f); 28(a); 30(b)(4), (7), and 30(f)(1); 32(a)(1), (4); 33(c); 34(b); 37(b)(2), (g); 45((d)(1), (e)(1). Rule 37(e) was abrogated. For the text of the amendinents, see 85 F.R.D. at 524-35.

3. 85 F.R.D. at 521 (Powell, J., dissenting).

4. See Order Amending the Federal Rules of Civil Procedure, 383 U.S. 1031, 1032-37 (1966) (Black, J., dissenting); Order Amending the Federal Rules of Civil Procedure, 368 U.S. 1012, 1012-14 (1961) (Douglas, J., dissenting).

5. See note 4 supra. 
least able to bear the burdens of delay, escalating legal fees, and rising court costs.

The amendments . . . should be rejected, and the [Judicial] Conference should be directed to initiate a thorough re-examination of the discovery rules that have become so central to the conduct of inodern civil litigation. ${ }^{6}$

The amendments are but another salvo, a half-hearted one accordmg to the dissent, in a war against "discovery abuse" that has been waged ever simce April 1976, when the American Bar Association, the Judicial Conference of the United States, and the Conference of Chief Justices sponsored the National Conference on the Causes of Popular Dissatisfaction with the Administration of Justice (popularly known as the Pound Conference). ${ }^{7}$ Probleins of discovery were discussed at the Conference but not in detail. ${ }^{8}$ In a report of the Conference Follow-up Task Force, ${ }^{9}$ discovery abuse was again reviewed in general terms, and it was left to an ABA Special Cominittee for the Study of Discovery Abuse $^{10}$ to suggest specific recommendations for reform. The Special Committee's report was issued in $1977,{ }^{11}$ and it became the basis for a revised report subsequently approved by the Judicial Conference of the United States and forwarded to the Supreine Court. ${ }^{12}$

Although the newly proinulgated amendments einbody the substance of nearly all the ABA Special Cominittee's recommendations, two notable ABA proposals were eliminated fron the report ultimately sent to the Supreme Court. One would have curtailed the scope of discovery by altering Rule 26 to permit discovery only of inatter relevant to the issues raised by the claims or defenses of the parties, rather than broader discovery relevant to the subject natter of the suit, as the rule now provides. ${ }^{13}$ The other proposal would have curtailed the use of discovery by amending Rule 33 to limit to thirty the number of inter-

6. 85 F.R.D. at 523 (Powell, J., dissenting).

7. See generally Addresses Delivered at the National Conference on the Causes of Popular Dissatisfaction with the Administration of Justice, 70 F.R.D. 79 (1976).

8. See Burger, Agenda for 2000 A.D. - A Necd for Systematic Anticipation, 70 F.R.D. 83, 9596 (1976); Kirkham, Complex Civil Litigation-Have Good Intentions Gone Awry?, 70 F.R.D. 199, 202-04, 210 (1976); Rifkind, Are We Asking Too Much of Our Courts?, 70 F.R.D. 96, 107 (1976).

9. American Bar Association, Report of Pound Conference Follow-up Task Force, 74 F.R.D. 159, 191-94 (1976).

10. Id. at 159 , 192-93.

11. ABa Litigation Section, Report of the Special Commitree for the Study of Discovery Abuse, (1977) [hereinafter cited as RePoRt of the SPECIAL Committee].

The Special Committee issued a second report in 1980, recommending amendments designated as Rules 26(g); 29; 30(c) and 30(d)(1), (d)(2); 33(a); 37(g). ABA Litigation Section, SeCOND REPORT FOR THE STUDY OF DISCOVERY ABUSE (1980).

12. Standing Committee on Rules of Practice and Procedure of the Judicial Conference of the United States and the Advisory Committee on Civil Rules, Revised Preliminary Draft of Proposed Amendments to the Federal Rules of Civil Procedure, 80 F.R.D. 323 (1979).

13. RePORT OF the SPECIAL Committee, supra note 11, at 2. 
rogatories a party could send without leave of court. ${ }^{14}$

Apparently, the dissenting Justices felt that these two recommendations would have provided the "genuinely effective reforms" they sought: "significant and substantial reforms," Justice Powell complamed, were "ultimately rejected . . . in large part."15 The unwillingness of the dissenters even to concur in what they conceded to be useful reforms, and their characterization of these amendments as mere "tinkering changes," suggests that at bottom they are not inuch interested in sanctioning abuses and streamlining procedures. The dissenters' basic concern is to curtail discovery, not to make it more efficient.

This Article explores the premises underlymg the dissenting Justices' position. Part I examines the nature of the new amendments and then analyzes the arguments of the dissent. Part II considers the policy issues implicated by a call to limit the general scope of discovery. The Article concludes that given the lack of workable proposals to limit the scope of discovery, the najority of the Supreme Court was wise not to withhold the useful, if not sweeping, changes represented by the new amendments.

\section{I \\ The Dissent's Implicit Call for Limitations on the SCOPE OF DISCOVERY}

\section{A. The Nature of the New Amendments}

The rules changes approved by the inajority of the Court aim for efficiency in litigation. Some of the new amendments imvolve only minor changes, but they have merit as time- and cost-saving devices. For example, the new version of Rule 5(d) provides that discovery papers served upon a party no longer must be filed automatically with the court; Rule 30(b)(4) permits parties to stipulate to a nonstenographic method of recording depositions; and Rule $30(\mathrm{~b})(1)$ allows courts to order the use of telephone depositions. Other amendments, such as those to Rules 32(a)(1) and (4) broadening the evidentiary use of depositions to conforn with the Federal Rules of Evidence, are more substantive.

Of the handful of amendments to which the dissent objects, only one is at all concerned with the scope of discovery. Denommated Rule 26(f), a new subsection provides for judicial intervention to limit, if necessary, the discovery process. It introduces a new device-the discovery conference-available at the request of any party and requiring the court to sit down with the litigants to formulate a formal discovery

14. Id. at 18 .

15. 85 F.R.D. at 522 (Powell, J., dissenting). 
plan, including appropriate limitations. ${ }^{16}$ Rule $37(\mathrm{~g})$ expressly provides for monetary sanctions to enforce this conference mechanism. An additional change to Rule 26, also recommended by the ABA Special Committee, would have gone further. That proposal-one of the two rejected ABA reforms apparently favored by the dissenting Justices-was designed to limit the use of discovery, permitting only discovery "relevant to issues raised by the claims or defenses of any party" rather than discovery "relevant to the subject matter in the pending action," as Rule 26(b)(1) continues to be phrased.

The remaming amendinents to which the dissent objects are concerned not with underlying discovery policy but with avoiding abuse and cutting costs. Rule 33, as altered, requires that a party electimg to turn over business records in heu of responding to interrogatories must specify the relevant records so as to permit the interrogating party to locate and identify thein as readily as could the responding party itself. Thus, the respondent is prevented from merely handing over the keys to a vast storage warehouse, leaving the interrogating party with the task of finding the needle in a haystack of documents. The other proposed change to Rule 33 would have allowed a party to propound only thirty interrogatories without a "showing of necessity" to the court. This proposal, which seems to be one the dissenting Justices favored, would have directly curtailed the use of discovery. Still, the more modest requirement that parties properly identify docunents unquestionably promotes efficient discovery and discourages a common abuse.

Rule 34 has been anended to require that a responding party pro-

16. Rule 26(f) provides for control of discovery by means of a discovery conference:

(f) Discovery Confereuce. At any time after commencement of an action the court may direct the attorneys for the parties to appear before it for a conference on the subject of discovery. The court shall do so upon motion by the attorney for any party if the motion includes:

(1) A statement of the issues as they then appear;

(2) A proposed plan and schedule of discovery;

(3) Any limitations proposed to be placed on discovery;

(4) Any other proposed orders with respect to discovery; aud

(5) A statement showing that the attorney making the motion has made a reasonable effort to reach agreement with opposing attorneys on the matters set forth in the motion.

Each party and his attorney are under a duty to participate in good faith in the framing of a discovery plan if a plan is proposed by the attorney for any party. Notice of the motion shall be served on all parties. Objections or additions to matters set forth in the motion shall be served not later than 10 days after service of the motion.

Following the discovery conference, the court shall enter an order tentatively identifying the issues for discovery purposes, establishing a plan and schedule for discovery, setting limitations on discovery, if any; and determinimg such other matters, including the allocation of expenses, as are necessary for the proper management of discovery in the action. An order may be altered or anended whenever justice so requires.

Subject to the right of a party who properly moves for a discovery conference to prompt convening of the conference, the court may combine the discovery conference with a pretrial conference authorized by Rule 16 .

FED. R. Clv. P. 26(f). 
duce documents in the inanner in which they are normally kept, or organize and label them according to the facts sought. This precludes a party from responding to requests for documents by producing them in random fashion with the hope that the discovering party will be unable to find or recognize the inore important items.

The changes in Rule 37 are calculated to strengthen the sanctions for noncompliance with discovery orders. The new version of Rule 37 authorizes judges to impose monetary as well as traditional sanctions to ensure comphance with judicial orders. Although the ABA Committee had recommended unlimited sanctions-including money-in all cases of "abuse,"17 the provision ultimately adopted authorizes "reasonable expenses, including attorney's fees" to be awarded a party only when its opponent "fails to participate in good faith in the framing of a discovery plan by agreement." 18 The sanction, then, is not as far-reaching as it might have been, but should add an incentive to agree to a judicially supervised discovery program.

In short, the alterations to which Justices Powell, Rehnquist, and Stewart dissent seem to be practical deterrents of costly discovery abuses. It is difficult to understand why the Justices would deny these concededly useful amendments. It seems that they would prefer to hold these reforms hostage, im the hope that such action would force the adoption of additional alterations that would cut down on the use of discovery.

\section{B. The Questionable Nature of the Dissent's Attacks on the Discovery Process}

There are a number of disturbing aspects to the arguinents advanced by the dissent.

First, in dissentimg to the adoption of the amendments to Rules 26, 33,34 , and 37 , the Justices failed to distinguish clearly between two very different types of discovery abuse. In one, parties directly violate federal rules provisions, for mstance, failing to respond to discovery requests within stated time limits, or giving obviously inadequate answers, or requesting information that clearly is outside the scope of discovery since it could not possibly lead to admissible evidence.

There is little dispute that this form of abuse should be elimmated.

17. The proposed amendment to Rule 37 would have allowed a trial court to exercise unlimited power to "impose upon any party or counsel such sanctions as may be just, including the payment of reasonable expenses and attorney's fees, if any party or counsel (i) fails without good cause to cooperate in the framing of an appropriate discovery plan by agreement . . . , or (ii) otherwise abuses the discovery process in seeking, inaking or resisting discovery." REPORT OF THE SPECIAL COMMitTEe, supra note 11, at 23-24.

18. FED. R. C1v. P. 37(g). 
Unfortunately, although the federal rules went into effect in $1938,{ }^{19}$ until recently judges have been extremely reluctant to apply available sanctions to curb direct violations of the rules. ${ }^{20}$ To a large extent this reluctance appears to have resulted from the judges' desire to encourage hitigants to solve their own problerns without court interference. ${ }^{21}$ Some judges have strained to find that failures to comply with simple regulations may have resulted from negligence rather than froin deliberate attempts to thwart the discovery process. ${ }^{22}$ Moreover, the prescribed sanctions normally have been directed toward the parties, with the court ordering dismissal of a plaintiff's action or granting a default judgment agamst a defendant. Courts traditionally have shied away from such forfeitures, not only because they dislike depriving a litigant of a legitimate cause or defense, but also because they are aware that to a great extent the fault is that of the attorney rather than of the client who bears the loss. ${ }^{23}$ Sanctions against attorneys, although authorized under a variety of provisions, have rarely been granted. ${ }^{24}$

Changes in the substance of the rules will not halt this direct type of abuse. Only when courts realize that they inust take charge and display a willingness to hand down serious sanctions against lawyers as well as agamst litigants will there be any effective control. In this respect, there lias been a notable change in the last few years. Spurred by the 1976 Supreme Court opinion in National Hockey League v. Metropolitan Hockey Club ${ }^{25}$ which strongly supported the use of sanctions, judges have applied and upheld sanctions in a much wider variety of situations. ${ }^{26}$ Nonetheless, it may be some tinie before lawyers clearly perceive that the courts will no longer be so willing to overlook abuses of discovery practice.

The other forn of "abuse" of discovery, distinct from violations of the letter of the rules, is the zealous overuse of permitted discovery procedures. Lawyers may demand disclosure of liundreds, perhaps thousands, of documents that could conceivably lead to admissible evi-

19. For a thorough history of the development and adoption of the first set of rules, see $4 \mathrm{C}$. Wright \& A. Miller, Federal Practice \& Procedure $\$ \$ 1003-1005$ (1969).

20. Renfrew, Discovery Sanctions: A Judicial Perspective, 67 Calif. L. Rev. 264, 271-78 (1979); Note, The Emerging Deterrence Orientation in the Imposition of Discovery Sanctions, 91 HARV. L. REv, 1033, 1034, 1038-44 (1978).

21. See, e.g. , SCM Societa Commerciale S.P.A. v. Industrial \& Commercial Research Corp., 72 F.R.D. 110, 112-13 (N.D. Tex. 1976). See generally Renfrew, supra note 20, at 272-73.

22. See, e.g., In re Professional Hockey Antitrust Litigation, 531 F.2d 1188 (3d Cir.), rev'd sub nom. National Hockey League v. Metropolitan Hockey Club, 427 U.S. 639 (1976); Ketchikan Cold Storage Co. v. State of Alaska, 491 P.2d 143 (Alaska 1971).

23. See Edgar v. Slaughter, 548 F.2d 770 (8th Cir. 1977); Renfrew, supra note 20, at 273-74.

24. See Note, Sanctions Imposed on Attomeys Who Abuse the Judicial Process, 44 U. CHI. L. REv. 619 (1977).

25. 427 U.S. 639 (1976).

26. See Note, supra note 20, at 1044-54. 
dence. They may take numerous, costly depositions and send voluminous interrogatories, all in an attempt to leave no stone unturned in establishing their clients' cases. Reformation of this practice of expansive discovery necessarily raises fundamental policy questions as to what the scope of discovery should be in our adversary system.

Although there is general agreement that steps should be taken to eliminate misuse of existing provisions, there is a substantial division of opinion $^{27}$ as to whether current provisions governing the scope of discovery need alteration. By failing to distinguish between the two different problems, clear violation and expansive use, the dissenting Justices tend to divert attention from the question whether rule changes are needed and toward the question of what changes can be made. The underlying policy issues regarding the proper scope of discovery tend to be overlooked in the drive for positive action to curb rule violations.

A second disturbing element of the dissent is the implication that discovery reform is primarily sought for the protection of the less affluent litigant who, too often, is forced to make an unfavorable settlement or to give up his case in the face of massive discovery demands by an opponent with much greater legal resources:

We may assume that discovery usually is conducted in good faith. Yet all too often, discovery practices enable the party with greater financial resources to prevail by exhausting the resources of a weaker opponent. The inere threat of delay or unbearable expense denies justice to inany actual or prospective titigants. ${ }^{28}$

Casting the dispute in terms of poorer versus richer litigants tends to appeal to emotion ratler than to address the issues. There is no relevant factual data to support the premise that discovery reform is primarily sought on behalf of financially weaker litigants. Indeed, much of the battle for hinitations appears to have been carried on by attorneys who represent affluent clients, often corporations, that most frequently find themselves in the role of defendants in gigantic cases involving consumer fraud, employment discrimination, or antitrust violations. ${ }^{29}$ In such cases it is the plaimtiff seeking to discover evidence supporting his case, and not the corporate defendant from whom such evidence is sought, who would suffer from restricting the scope of discovery.

Nor is there any study or authority that establishes that the problem of "unbearable expense," when it arises, requires a major limitation on the scope of discovery instead of the ad hoc control available

27. 85 F.R.D. at 522-23 (Powell, J., dissenting).

28. Id. at 523 .

29. See Kirkham, supra note 8, at 203-07. 
under existing provisions. ${ }^{30}$ It would be a sad irony if reforms ultimately prevented the less affluent litigant from presenting a valid case that without discovery he could not prove. ${ }^{31}$ By miscasting the nature of the dispute, the dissenting Justices fail to consider the negative aspects that scope limitation could have on the very litigants about whom they profess concern.

A third problem is the claim that discovery abuse is quite pervasive, perhaps affecting the majority of civil cases. According to Justice Powell, "[d]elay and excessive expense now characterize a large percentage of all civil hitigation. The problens arise in significant part, as every judge and litigator knows, from abuse of the discovery procedures available under the Rules." 32 But "every judge and litigator" does not agree with Justice Powell. Indeed, those who have thoughtfully studied the available evidence have found the frequency of abuse, in the form either of violation or overuse, to be greatly exaggerated, although it constitutes a very serious problem when it occurs..$^{33}$ As one federal judge has said, "[a]lthough widespread, the dissatisfaction with the discovery process is directed at a limited field of cases. Few, if any, abuses of discovery exist in connection with ordmary hitigation. . . . The rub occurs in the so-called complex cases. Here the abuse-of-discovery-cry becomes a reahty." 34 If discovery abuse is confined to a relatively few cases, a call for across-the-board limitations is in reality no more than a covert call for a fundamental policy change that would deter litigants from obtaining vital information in the inany cases where no abuse exists. ${ }^{35}$

\section{The Political Basis of the Dissent and The Dangers of Politicized Rulemaking}

The dissenting opimion is interesting as a political document. When analyzed im detail it reveals far more than an attempt to effect a cure for discovery abuse. It suggests that the dissenting Justices are more concerned with providing relief for certam interest groups frequently mvolved in complex litigation than with curtailing discovery abuse generally.

The Justices' opposition to the cluster of discovery amendments reflects an apparent conviction that even when there is no abuse in terms of violations of rules or orders, the availability and use of discov-

30. See note 16 supra.

31. See Clark, Special Pleading in the "Big Case," 21 F.R.D. 45, 52-53 (1957).

32. 85 F.R.D. at 522-23 (Powell, J., dissenting).

33. Schroeder \& Frank, The Proposed Changes in the Discovery Rules, 1978 ARIz. ST. L.J. 475, 476-78, 492

34. Pollack, Discovery-Its Abuse and Correction, 80 F.R.D. 219, 222 (1978).

35. See Schroeder \& Frank, supra note 33, at 491-93. 
ery achieves unfair results by burdening organizational litigants. Because it is clear that the ainendments to Rules 33,34 , and 37 were designed to cut costs and to favor hitigants who confront large organizations that produce documents in deliberate disarray ${ }^{36}$ or simply hand over the keys to the warehouse, ${ }^{37}$ the dissenting Justices appear to be concerned that corporations received no quid pro quo in discovery reform, such as the proposed restrictions on the scope and number of interrogatories. Otherwise it is difficult to understand the dissenters' opposition to changes that are nost beneficial to "less affluent" litigants.

That Justice Powell and his dissenting brethren are interested in a different balance of discovery vis-à-vis various parties to litigation is also indicated by the subtle call for congressional intervention. Simce the battle in the Court had been lost, they apparently wanted Congress to prevent implementation of the new rules and, as it did with the Federal Rules of Evidence, ${ }^{38}$ debate the propriety of specific proposals. That would have set up a typical lobbying situation, ${ }^{39}$ with the ultimate coinproinise likely to include provisions more favorable to corporate defendants. There can be no doubt that Justice Powell sought to involke congressional revision: "I simply believe that Congress' acceptance of these tinkering changes will delay for years the adoption of genuinely effective reforins. . . Favorable congressional action on these amendments will create complacency and encourage inertia." 40 As the Justices certainly know, new rules need not be approved or accepted by Congress. Unless Congress takes action within nimety days after it receives the rules, they automatically take effect. ${ }^{41}$ To speak of "Congress' acceptance" and "favorable congressional action" in this context is akin to implying that the Supreme Court approves the substance of those decisions for which it denies certiorari. One might consider this no more than a slip of the pen were it not for the fact that a footnote hammers home the notion that Congress is responsible for the implementation of the rules. In speaking of the Court's own role in the ruleinaking process, the dissent observes, "Congress should bear in mind that our approval of proposed Rules is more a certification that they are the products of proper procedures than a considered judgment

36. See Advisory Committee Note to the Amendment to Rule 34(b), 85 F.R.D. at 532 (quoting RePort of THE SPECIAL CoMmitTeE, supra note 11, at 22).

37. See Advisory Committee Note to the Amendment to Rule 33(c), 85 F.R.D. at 53 I; REPORT of THE SPECIAL COMMITTEE, supra note 11, at 20-21.

38. See Friedenthal, The Rulemaking Power of the Supreme Court: A Contemporary Crisis, 27 STAN. L. REV. 673, 675 (1975).

39. See id. at 673-74.

40. 85 F.R.D. at 523 (Powell, J., dissenting) (emphasis added).

41. See 28 U.S.C. $\$ 2072$ (1976). 
on the merits of the proposals themselves." 42

Turning the rulemaking process over to Congress, however, would not be a positive development. It is far better to leave procedural reform in the hands of the Supreme Court and its advisory committees, whose meinbers are chosen for their dedication to improvement of the judicial process, than to rely on elected pohticians who inust satisfy many constituents on a variety of issues. ${ }^{43}$ Furthermore, the Court and its advisors are far more knowledgeable about court practices. Moreover, since any changes made by Congress must be embodied in a proposed bill, discussed and approved by all the relevant committees, passed by both houses after reconciliation of any differences and, finally, signed by the President, Congress has far less flexibility than does the Court to experiment with various proposals and to alter them if necessary. It is institutionally shortsighted, then, to appeal to Congress to strike a new political balance in adopting procedural changes.

II

The Policy Issues Implicated by a CALl For Limitations ON THE SCOPE OF Discovery

\section{A. Discovery as a Means to Ascertain if a Suspected Case Does in Fact Exist}

At the heart of the controversy over the scope of discovery is the question whether a potential plaintiff should be entitled to bring an action solely on a good faith behef that a valid cause exists, without hard evidence that it does. The issue is hardly a new one. It has arisen time and again in a variety of contexts ever since the federal rules were mtroduced with their concept of notice pleading, where a plaintiff need only make "a short plain statement of a claim," 44 rather than the "statement of facts setting forth a cause of action" then required by the codes of most states. ${ }^{45}$

The modern form of notice pleading has been challenged primarily on behalf of defendants in civil actions. ${ }^{46}$ It is always to a defendant's advantage to require the plaintiff to pinpoint its case specifically and in detail. First, if the case is based primarily on speculation, the plaimtiff may be unable to allege sufficient facts to sustain the coinplaint and the action can be dismissed immediately. Second, even if the com-

42. 85 F.R.D. at 521 n.l (Powell, J., dissenting) (emphasis added).

43. See generally Friedenthal, supra note 38, at 673-77.

44. FED. R. CIV. P. 8(a).

45. See C. Clark, Handbook of the Law of Code Pleading $\$ \S 8,35$ (2d ed. 1947). A number of states still adhere to the code formulation. See, e.g., Cal. CIv. Proc. CoDE $\$ 425.10$ (West 1973); S.C. CoDE \& 15-13-220 (1977).

46. See Clark, supra note 31 , at $48-52$. 
plaint is sufficient, it necessarily narrows the range of facts that the plaintiff will be allowed to discover and to prove at trial. If plaintiff's attorney has erred at the pleading stage as to the specific facts by which a valid case for his chent could be estabhished, defendant can thwart successful prosecution of the action by keeping out vital facts on the ground that they were not pleaded and, hence, are not relevant. ${ }^{47}$

Once it becaune clear that the battle for a return to the code formulation of pleading was irretrievably lost, other devices were utilized to raise the saine issue in different contexts. For exainple, there have been attempts to convert the pretrial conference mechanism ${ }^{48}$ into a second pleading, so that the desired specificity could be introduced into the process, albeit at a later stage. ${ }^{49}$ And defendants frequently argue, ${ }^{50}$ occasionally with success, ${ }^{51}$ that certain types of cases are so unique that they should be dismissed in the absence of specific pleading of detailed facts showing that a right to relief exists. Sigmificantly, the two Pound Conference participants critical of the discovery process both argued that discovery should not begin until the plaintiff has stated a specific and colorable clami. ${ }^{52}$

It is not surprising to find that the battle over specificity has shifted froin pleading to discovery. The relationship between the policy of pleading and that of discovery is obvious. The very purpose of permitting pleadings based upon good faith speculation must be to permit plaintiffs to einploy the discovery provisions to determine whether a valid case in fact exists. If plaintiff had the resources and ability to ascertain all the facts without resort to the formal discovery process, there would be no need, of course, to permit any but the inost specific allegations. Conversely, it would not matter that general pleadings sufficed if discovery could nevertheless be curtailed, thus preventing or hindering plaintiffs from ascertaining if, and on what facts, valid claims exist.

From a theoretical point of view, the current practice of allowing general pleadings and extensive discovery cannot seriously be chal-

47. See Messick v. Turnage, 240 N.C. 625,83 S.E.2d 654 (1954).

48. FED. R. CIV. P. 16.

49. See, e.g., Padovani v. Bruchhausen, 293 F.2d 546 (2d Cir. 1961).

50. E.g., Walker Distrib. Co. v. Lucky Lager Brewing Co., 323 F.2d 1, 3 (9th Cir. 1963); see Clark, supra note 31 , at $48-52$.

51. See, e.g., Martin v. New York State Dept. of Mental Hygiene, 588 F.2d 371 (2d Cir. 1978).

52. See Rifkind, supra note 8, at 106-07 (advocating a showing of "probable merit" before discovery, to reduce litigation instigated in the hope that discovery will reveal a claim); Kirkham, supra note 8, at 202-03:

When notice pleading dumps into the lap of a court an enormous controversy without the slightest guide to what the court is asked to decide; when discovery-totally unlinited because no issue is framed-nulls over millions of papers . . . , we should, I thimk, consider whether noble experiments lave gone awry. 
lenged. There seems to be little reason why litigants sliould be prevented from establishing legitimate claims im actions in which the admissible facts are to be found only in the files and minds of opposing parties. Similarly, the Supreine Court should not give in to charges of abuse by lawyers who, rather transparently, are merely acting as lobbyists for their particular clientele. The practical problems, however, are not so easily treated. There are cases in which extensive discovery results in costs well out of proportion to the dispute. ${ }^{53}$ Nevertheless, lawyers push on with their inquiries-not so much to build their fees, as is sometimes suggested, ${ }^{54}$ but to ensure that after the case is completed the lawyers will not be subjected to malpractice claims following the sudden appearance of favorable, hitherto undiscovered docuinents or testimony. ${ }^{55}$ The fact that some clients can afford such extensive discovery does not alter the fact that it often wastes both time and money.

The inherent difficulty with proposals to limit the scope of discovery, however, is that they apply to every case, including those in which discovery will cover a broad base but will not necessarily be extensive and costly, those in which costly, time-consuming discovery is justifiable, and those in which limits should legitimately be imposed. There is but one obvious solution. Trial judges must be willing to concern themselves on a case-by-case basis to determine when a litigant has gone too far. ${ }^{56}$ It is not a question of scope so much as a question whether a party has raked over the ground again and again to the point that the cost of additional depositions or other discovery would be too high a price to pay for the remote chance that the procedure would yield any additional information of value.

Even before the inost recent rules amendments, trial courts had substantial power to control abuses. ${ }^{57}$ That power has now been increased by the new discovery conference provision. Although discov-

53. See, e.g., Pollack, supra note 34, at 222.

54. Id. at 223.

55. Barthold, "Negligence" in Discovery: No Paper Tiger, 6 Lmigation, No. 1, at 39 (1979); Renfrew, supra note 20, at 274.

56. See Peckham, The Federal Judge as a Case Manager: The New Rule in Guiding a Case from Filing to Disposition, 69 CALIF. L. REv. 770, 780, 800 (1981).

For an interesting discussion of proposed special discovery rules to be applied in actions designated as "complex" by the trial court, see Kaminsky, Proposed Federal Discovery Rules for Complex Civil Litigation, 48 Fordham L. Rev. 907 (1980).

57. Pollack, supra note 34, at 223-24:

The burning question currently is whether a Rule change is needed to limit the scope of discovery to "issues" or whether judicial control-personal supervision and management by the trial Judge-is a more promising approacli that inust be provided early and often in the discovery process.

The trial Judge and the Court have ample discretion within the framework of the present Rules to take over case management froin its inception and to create innovative regulations not inconsistent with the Rules of Civil Procedure. 
ery conferences certainly involve costs to the litigants, court appearances to argue about the vahidity of specific discovery requests are also expensive. Thus, even if one could agree on the legitimacy of an across-the-board limitation on the scope of discovery, the cost of court appearances to apply such a limitation might outstrip its advantages. The Special Committee itself recognized this problem even while proposing to alter the scope of discovery by requiring it to be relevant to "issues" pleaded rather than to "the subject matter" of the case: "Determining when discovery spills beyond 'issues' and into 'subject matter' will not always be easy." "58 If a case-by-case determination must be made, at least it should be made in an efficient, informal setting.

\section{B. Discovery as a Catalyst for the Growth of Substantive Remedies}

Arguments regarding the scope of discovery typically have not dealt with the role discovery has played in the evolution of substantive law. It is clear, however, that over the years developments in areas such as products liability, employment discrimmation, and consumer protection have been the result at least partly of broad-ranging discovery provisions. For example, lawyers would not have pushed in the courts and in the legislatures for expanded causes of action hinged on proof that defendants knew or slould have known of a product's danger, if such proof were normally unavailable. The ability of plaintiffs' attorneys to obtain a corporate defendant's records, to depose corporate employees, and to send searching interrogatories has had a substantial impact $^{59}$ in particular areas of law, and is one important factor in the dramatic imcrease in cases filed.

This growth in litigation was largely unforeseen when the discovery rules were first introduced. There was no conscious monitoring of the long-term effects on substantive law that might result. Had there been, courts and legislators might well have taken different approaches. Perhaps special tribunals or admimistrative panels would have been used to try certain types of cases; liability or damages might have been limited or curtailed. Instead, development las taken place along traditional common law lines to a point where courts today are heavily burdened by plaintiffs wlo sometimes treat the judicial system as if it were a gigantic slot machine. It is therefore understandable that defendants

58. Report of the Special Committee, supra note 11, at 3. See generally Schroeder \& Frank, supra note 33, at 479-81.

59. The vital role of discovery in estabhishing a plaintiffs employment discrimination case is discussed in Myer, Development of a Plaintiffs Fair Employment Practices Case, 5 Litigation, No. 2, at 8 (1979). Cf. Galane, Proving Punitive Damages in Business Tort Litigation, 2 LitigaTION, No. 3, at 24 (1976) (observing the importance of discovery in making out claims of bad faith in suits for commercial torts). 
and their attorneys argue for discovery limitations; in a sense, they are "victims" of the discovery process.

Nevertheless, it seens clear that this concern with expansive liability is not an appropriate reason for limiting the general scope of discovery. Valid claims for relief froin recognized injuries should not be thwarted by altering procedural rules to make it impossible for plaintiffs to obtain hard evidence. If the results of a particular substantive doctrine are unsatisfactory, the answer is to face the matter squarely and change that substantive doctrine, its proof requirements, or its remedies.

\section{CONCLUSION}

Few lawyers or legal scholars would argue agamst a set of rules designed to ensure that, without court interference, discovery in every case would be confined strictly to matters for which discovery is required and only in proportion to the size of the case and the need for the inforination. The problem is that in spite of the considerable amount of study given to discovery, no one has yet been able to devise such a self-executing set of ideal rules.

The two rejected ABA proposals designed to impose general discovery limitations were so hedged with exceptions that they did not really present a viable alternative to case-by-case supervision. They had none of the advantages desired of easily applied automatic limitations. The proposal to limit discovery to "issues raised by the claims or defenses of any party" was so imprecise that it clearly would have spawned case-by-case arguments as to what is included in an "issue." Even the Special Committee that drafted the proposal recognized that its chief impact would be on the decisions of judges who were called upon to rule on objections to specific requests for disclosure..$^{60}$

Similarly, the proposal to limit to thirty the number of imterrogatories that could be served witlout showing good cause would also be likely to result in numerous court appearances, either to determine the difficult question of what multiple inquiries should be counted as a single interrogatory, or to obtain permission to serve an additional set of imterrogatories. ${ }^{61}$ Althouglı an arbitrary limitation on the number of

60. See Report of THE SPECIAL Commitree, supra note 11 , at 3.

61. See Letter of the Advisory Committee on Federal Civil Rules to the Committee on Rules of Practice and Procedure of the Judicial Conference of the United States (June 14, 1979), reprinted in 85 F.R.D. 538, 543-44 (1980) [hereinafter cited as Advisory Committee Letter]. To avoid abuse of the rule through use of nultipart interrogatories, the proposal required that "[e]ach interrogatory shall consist of a single question." REPORT OF THE SPECIAL COMMITTEE, supra note 11, at 18. But even the Special Committee recognized that such a thirty-question limit would often be insufficient and unfair. It therefore recommended that courts in effect violate the rule by construing "as one interrogatory" several related questions concerning the names and locations of 
interrogatories would be realistic in some cases, it would be ridiculous in others. Interrogatories are, of course, the least expensive inethod of obtaining information. ${ }^{62}$ If trial courts rigidly refused to find good cause to avoid the limitation, litigants would resort to depositions, a far more costly way to obtain basic information. For the party who could not afford depositions, such a limitation on interrogatories would impose an unjustifiable restrietion on his ability to prosecute or defend his case.

Reform of the scope of discovery can take one of two forms, then. Either trial judges will be required to supervise the discovery process on a case-by-case basis, producing tailored results but at a certain cost to the judicial system, or overall limitations will be placed on the scope of discovery, resulting in unfairness in some cases and still requirmg frequent judicial involvement. In proinulgatimg the new amendments, the Supreme Court wisely opted for the former alternative as the lesser evil. ${ }^{63}$ The efforts of the dissenters, to the extent that they may have hoped to use discovery abuse as a smokescreen to mask attempts to overcome what they believed to be undesirable substantive developments, were misdirected. The position of the dissenting Justices would have inade sense only if they had been able to set out meaningful, workable reforms to prevent violations of the rules and to curb overuse of the discovery devices. It would be foohsh to withhold admittedly useful changes that can go far toward eliminating serious abuses, in the hope that yet another study might result in a miraculous new approach that would solve all the problems with discovery practice.

witnesses or the existence, location and custodians of documents or physical evidence. REPORT OF THE SPEClal COMmitteE, supra note 11, at 20.

62. See Advisory Committee Letter, supra note 61, at 543.

63. The only provision adopted that deals with the scope of discovery is that which provides for the discovery conference, where the parties and the judge may establish a detailed program for discovery in each particular case. See text accompanying note 16 supra. 